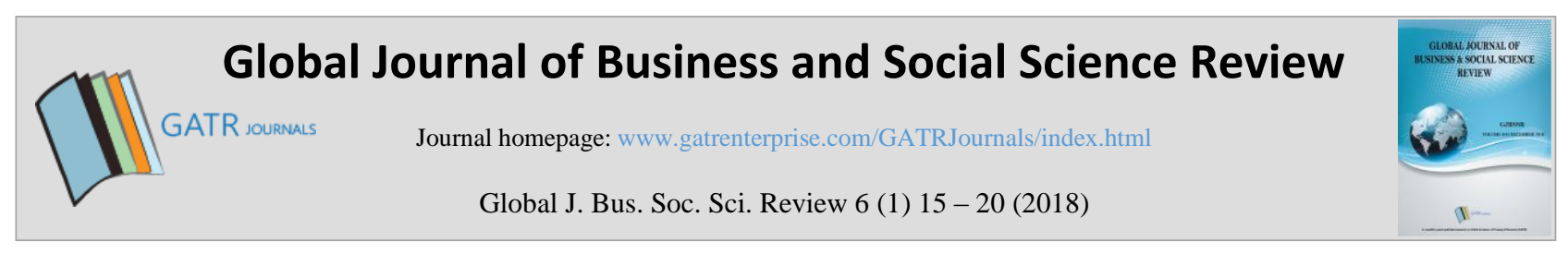

\title{
Entrepreneurial Intentions of University Students in Bandung, Indonesia
}

\author{
F.X. Supriyono ${ }^{1}$, Christian Wibisono ${ }^{2 *}$ \\ ${ }^{1,2}$ Parahyangan Catholic University, Ciumbuleuit No. 94, 40141, Bandung, Indonesia
}

\begin{abstract}
Objective - The purpose of this paper is to describe entrepreneurial intentions (EI) among university students in Bandung, West Java, Indonesia.

Methodology/Technique - Adapting the theory of planned behavior, this study measures entrepreneurial self-efficacy, risk tolerance, and desirability of self-employment as antecedents of entrepreneurial intention. Using cross-sectional data from 190 students in Bandung, the analysis uses multiple regression analysis to investigate the relationship among the variables.

Findings - The findings show that entrepreneurial self-efficacy and desirability of self-employment have a significant impact on entrepreneurial intentions. Desirability of working for others and risk-averse personalities were found to be suppressor variables, while risk-taker personalities were found to be insignificant.

Novelty - The study contributes to the field of entrepreneurial intention research as it investigates the antecedents of entrepreneurial intentions among university students in Bandung based on samples taken from 8 different universities.

Type of Paper: Review.
\end{abstract}

Keywords: Entrepreneurship; Indonesia; Intentions; Motivation; Students.

JEL Classification: L26, I23.

\section{Introduction}

It comes as no surprise that the motivation for entrepreneurship is one of the most popular topics investigated by many researchers (Segal, Borgia and Schoenfeld, 2005). In the ASEAN context in general, and particularly in Indonesia, what makes this topic highly relevant in a global context is the number of mechanisms and policies created by the Indonesian government to support entrepreneurs: infrastructure, funding, advisory services, and training courses. All of these programs have been created to foster entrepreneurial growth in the country, with a particular focus on young entrepreneurs. This paper aims to contribute to an understanding of what motivates young people in Indonesia to become entrepreneurs, and

\footnotetext{
* Paper Info: Revised: December 26, 2017

Accepted: February 25, 2018

Corresponding author:

E-mail: christian.wibisono@unpar.ac.id

Affiliation: Faculty of Economy, Parahyangan Catholic University
} 
thereby assist the Indonesian government to create more suitable programs to attract young people to entrepreneurship.

Many researchers have attempted to study the predictors of entrepreneurial intentions: entrepreneurial education (Fietze and Boyd, 2017), gender, personality traits (Miranda et al, 2017; Yukongdi and Lopa, 2017; Mustafa et al, 2016), student learning style and ideas (Molalei et al, 2014), social networking, risktolerance, self-efficacy, and the need for achievement (Elali and Yacoub, 2016; Laviolette et al, 2012). Other research focuses on whether universities and entrepreneurial education motivate students to pursue entrepreneurship (Moreno et al, 2012; Trivedi, 2016; Aloulou, 2016, Fietze and Boyd, 2017).

Despite the importance placed on fostering entrepreneurial intentions among students, few studies have been conducted on this topic in Indonesia (Ridha et al, 2017). Furthermore, much of the existing literature on entrepreneurship focuses on adult entrepreneurs (Turker and Selcuk, 2009). However, as the foundation of economic growth of a country, it is very important that young people are motivated to pursue careers as entrepreneurs (Gelaidan and Abdullateef, 2017).

Hence, this research focuses on young people in Bandung; a city sparkling with many successful entrepreneurs, particularly in the creative industry, zooming in on the entrepreneurial intention of university students. Ridwan Kamil, the Mayor of Bandung, has also proclaimed the city as a center for the creative industry, adopting the tagline "Bandung: the Emerging Creative City". Mr. Kamil has also announced his target to create 1,000 new entrepreneurs in Bandung. This study uses the framework introduced by Segal, Borgia and Schoenfeld (2005) to measure entrepreneurial intention using 3 independent variables: entrepreneurial self-efficacy, tolerance for risk, and desirability for self-employment. Therefore, the research questions of this study can be formulated as follows:

RQ1: Will entrepreneurial self-efficacy influence the entrepreneurial intention of university students?

RQ2: Will tolerance for risk influence the entrepreneurial intention of university students?

RQ3: Will desirability of self-employment influence the entrepreneurial intention of university students?

\section{Literature Review}

There are several studies examining entrepreneurial intentions ('EI'). Early research in the entrepreneurial field focused on establishing the relationship between certain personality traits such as the need for achievement, the need for affiliation, and the need for power (McClelland, 1961). Another dominant theory in this area is the Theory of Reasoned Action (TRA) (Ajzen and Fishbein, 1980) and the Theory of Planned Behavior (TPB) (Ajzen, 1991). According to those theories, entrepreneurial intention will affect a persons' motivation to pursue entrepreneurship.

Other schools of research on entrepreneurial intention examine the effect of environmental factors on entrepreneurial intention: demography, family business experience, education level, and access to capital (Mustafa et al, 2016). A study by Sandhu, Sidique and Riaz (2011) categorizes barriers to becoming an entrepreneur into 3 categories: psychological, institutional, and demographic. Further, recent research on entrepreneurial intentions emphasizes how personal experiences shape EI. Quan (2011), for example, analyzes how prior experience and social networks influence EI, while Gelaidan and Abdullateef (2017) focus on how educational support affects EI.

Entrepreneurial intention refers to the planning and implementation of business ideas, which is influenced by mental processes. Elali and Yacoub (2016) state that EI refers to the conscious intention to start a new business venture at some point in the future. However, those intentions may precede one's actual behavior (Mustafa et al, 2016). This particular research operationalizes EI as the student's intention to pursue entrepreneurship in the future. 
Sandhu, Sidieq and Riaz (2011) argue that prior research shows that barriers faced by actual entrepreneurs may be different from the ones faced by growing entrepreneurs (for example, students aspiring to become entrepreneurs). Actual entrepreneurs primarily face institutional barriers, such as lack of government assistance, lack of access to capital, and lack of access to consultancy services. Meanwhile, growing entrepreneurs primarily deal with psychological barriers. This study focuses on self-efficacy, tolerance for risk, and desirability of self-employment as antecedents of entrepreneurial intentions among students in Indonesia.

\subsection{Entrepreneurial Self-efficacy and Entrepreneurial Intentions}

In the trait-based approach, self-efficacy has received the most attention and empirical support (Mustafa et al, 2016). Elali and Yacoub (2016) state that self-efficacy, which refers to one's perceived ease or difficulty to become an entrepreneur, is one of the most critical antecedents of entrepreneurial intention. Hence, the greater an individual's self-belief is, the stronger their entrepreneurial intentions will be. Thus, the first hypothesis of this research is:

H1: Entrepreneurial self-efficacy influences entrepreneurial intentions.

\subsection{Tolerance for Risk and Entrepreneurial Intentions}

Many successful entrepreneurs are known for their boldness in taking calculated risks. Some early scholars focusing on the traits of entrepreneurs argue that they have a greater propensity for risk than others. Recent research has identified that it is not risk propensity, but risk perception, that is influential on entrepreneurial intentions (Tognazzo et al, 2017). Yukongdi and Lopa (2017) also hypothesizes that a risktaking tendency has a positive influence on entrepreneurial intention. Hence, the second hypothesis of this research is:

$\mathrm{H} 2$ : Tolerance for risk influences entrepreneurial intentions.

\subsection{Desirability of Self-employment and Entrepreneurial Intentions}

Another predictor for entrepreneurial intention, based on Ajzen's model, is attitude. Attitude, whether it is negative or positive, depends on whether a person feels what the consequences or the output of certain behavior would be. If a person considers that consequences of behavior will be positive, they will have a positive attitude towards that behavior. Miranda et al (2017) calls this concept "perceived utility". Their recent research offers a model of entrepreneurial intention in which the choice to pursue entrepreneurship is based on a person's perception towards the income anticipated, the amount of work anticipated to achieve this income, and the risk involved. When a student believes self-employment will lead to a more valuable outcome than working for others, they will have greater entrepreneurial intentions (Segal, Borgia and Schoenfeld, 2005). Based on this, the third hypothesis of the research is:

H3: Desirability of self-employment influences entrepreneurial intentions.

\section{Methodology}

The research comprises descriptive and quantitative research. The research model has been adapted from Segal, Borgia and Schoenfeld (2005). There are 3 independent variables: entrepreneurial self-efficacy, tolerance for risk and desirability of self-employment. There is one dependent variable, namely entrepreneurial intention. 


\subsection{Data Collection}

Data is collected from 190 university students from several reputable universities in Bandung: UNPAR, ITB, ITENAS, Maranatha, Telkom, UNISBA, UNPAD, UPI, UNS, and Widyatama. Quota sampling was not used in this study, so the results cannot be generalized. The sampling method consists of convenience sampling.

The data is collected using questionnaires distributed through an online survey platform. The questionnaire employs a likert-scale to record the responses of respondents. The data analysis employs SPSS tools by performing multiple regression analysis to test the hypotheses.

\subsection{Revised Conceptual Framework}

The reliability of the instruments was tested using Cronbach's Alpha. The result of that test shows that the construct's indicator is reliable as the Cronbach's Alpha value is 0.692 (higher than 0.60 ). The validity has been tested using the factor analysis. Six factors were derived from the factor analysis and the conceptual framework of this research is being revised.

\section{Results}

Of the 190 respondents, the majority of them are aged between 21 to 24 year-old (107 respondents). The second largest age group was 19 to 20 year-olds (64 respondents). In addition, the respondents' alma mater is distributed unevenly: UNPAR (60 respondents), ITB (41 respondents), UNPAD (22 respondents), TELKOM University (17 respondents), UNISBA (14 respondents), ITENAS (13 respondents), Maranatha Christian University (13 respondents), UPI ( 7 respondents) and UNS ( 2 respondents). Most of the respondent's parents are employed as entrepreneurs (75 respondents), private employees (46 respondents), civil servants (36 respondents) and the remaining consist of: university lecturers, doctors, army personnel, etc. (33 respondents).

\subsection{Hypotheses Testing}

To test the hypotheses proposed in this research, an F-test is conducted using multiple regression analysis by using IBM SPSS Statistics 20. The Stepwise Method has been used in multiple regression analysis. The Ftest shows that the model is significant, which means that entrepreneurial self-efficacy (SE), desirability of working for others (DWO), risk adversity (risk_averse), and desirability of self-employment (DSE) simultaneously influence entrepreneurial intentions.

The correlation value of $\mathrm{R}$ between the independent and dependent variables is 0.743 , while the adjusted $\mathrm{R}$-Square value is 0.543 . This means that the independent variable contribution to the variability in the dependent variable is $54.3 \%$, while the remaining variability was caused by factors not included in this study. The test also shows that entrepreneurial self-efficacy has a positive influence on EI with a beta coefficient value of 0.265 , while desirability of working for others has a beta coefficient value of -0.332 , risk adverse personality -0.248 , and desirability of self-employment 0.218 . The regression model of this research is: Y: $0.601-0.332 \mathrm{DWO}+0.265 \mathrm{SE}-0.248$ risk_averse + 0.218 DSE + e.

\section{Discussion}

These findings are consistent with the findings of many previous studies on entrepreneurial intention (Laviolette et al, 2012; Mustafa et al, 2016; Yukongdi and Lopa, 2017). Therefore, the more confidence a student has in themselves to be able to carry out duties and tasks needed to live a successful life as an entrepreneur, the greater the entrepreneurial intention of that particular person will be. Therefore, $\mathrm{H} 1$ is accepted. 
Risk-averse personality traits have a negative influence on entrepreneurial intention with a beta coefficient value of -0.248 however, risk-taker personality traits did not significantly contribute to the regression model. This may be because students and young people in general show greater tolerance for risk, so it is not directly relevant to their entrepreneurial intentions. This means that $\mathrm{H} 2 \mathrm{a}$ is rejected while $\mathrm{H} 2 \mathrm{~b}$ is accepted. Respondents who see stability of income and stability in their career as one of their primary future objectives tend to be less willing to be an entrepreneur.

Desirability of self-employment also has a positive influence on entrepreneurial intention with a beta coefficient value of 0.218 , while desirability of working for others has a negative influence on entrepreneurial intention with a beta coefficient value of 0.322 . This means that both $\mathrm{H} 3 \mathrm{a}$ and H3b were accepted. Those results support the TPB model (Ajzen, 1991) which states that conscious intentions are the results of attitudes, subjective norms, and behavioral controls (Mustafa et al, 2016). Hence, the more positive attitude people have towards something, the greater their intention will be to exhibit that behavior.

\section{Conclusion}

Indonesia is a country with 250 million citizens and faces a huge challenge as a nation: to facilitate the prosperity of its citizens. One of the most critical factors to support economic growth and stability is entrepreneurship (Anggadwita et al, 2017). Hence, studies relating to entrepreneurial intentions, particularly in young people, are particularly important.

This study offers a new perspective to understanding the motives of young people to pursue entrepreneurial careers. The model in this study demonstrates that entrepreneurial self-efficacy, desirability for self-employment, and risk-averse personality traits all have a significant influence on a person's intention to pursue entrepreneurship. In light of these findings, educators should recognize the importance for young people to feel confident in their chance of succeeding in entrepreneurship. Entrepreneurial self-efficacy, as the model in this study has shown, is important for these young people.

Desirability of self-employment is also an important antecedent in the present model, hence it is important that university students understand the benefits of a potential career as an entrepreneur. To facilitate this, universities could invite successful entrepreneurs to present guest lectures, to provide students with role models and to motivate them to become entrepreneurs in the future. Educators should also encourage students to adopt a calculated risk-taker personality, to strengthen their entrepreneurial intentions.

\section{References}

Ajzen, I. (1991). The theory of planned behavior. Organizational behavior and human decision processes, 50(2), 179 211.

Ajzen, I., \& Fishbein, M. (1980). Understanding attitudes and predicting social behaviour.

Aloulou, W. J. (2016). Predicting entrepreneurial intentions of final year Saudi university business students by applying the theory of planned behavior. Journal of Small Business and Enterprise Development, 23(4), 1142-1164.

Anggadwita, G., Luturlean, B. S., Ramadani, V., \& Ratten, V. (2017). Socio-cultural environments and emerging economy entrepreneurship: Women entrepreneurs in Indonesia. Journal of Entrepreneurship in Emerging Economies, 9(1), 85-96.

Elali, W., \& Al-Yacoub, B. (2016). Factors affecting entrepreneurial intentions among Kuwaitis. World Journal of Entrepreneurship, Management and Sustainable Development, 12(1), 18-34.

Fietze, S., \& Boyd, B. (2017). Entrepreneurial intention of Danish students: a correspondence analysis. International Journal of Entrepreneurial Behavior \& Research, 23(4), 656-672.

Gelaidan, H. M., \& Abdullateef, A. O. (2017). Entrepreneurial intentions of business students in Malaysia: The role of self-confidence, educational and relation support. Journal of Small Business and Enterprise Development, 24(1), 54-67.

Laviolette, E. M., Radu Lefebvre, M., \& Brunel, O. (2012). The impact of story bound entrepreneurial role models on self-efficacy and entrepreneurial intention. International Journal of Entrepreneurial Behavior \& Research, 18(6), 720-742. 
McClelland, D. C. (1961). The achievement society. Princenton, NJ: Von Nostrand.

Miranda, F. J., Chamorro-Mera, A., Rubio, S., \& Pérez-Mayo, J. (2017). Academic entrepreneurial intention: the role of gender. International Journal of Gender and Entrepreneurship, 9(1), 66-86.

Molaei, R., Reza Zali, M., Hasan Mobaraki, M., \& Yadollahi Farsi, J. (2014). The impact of entrepreneurial ideas and cognitive style on students entrepreneurial intention. Journal of Entrepreneurship in Emerging Economies, 6(2), $140-162$.

De Jorge-Moreno, J., Laborda Castillo, L., \& Sanz Triguero, M. (2012). The effect of business and economics education programs on students' entrepreneurial intention. European Journal of Training and Development, 36(4), 409-425.

Mustafa, M. J., Hernandez, E., Mahon, C., \& Chee, L. K. (2016). Entrepreneurial intentions of university students in an emerging economy: The influence of university support and proactive personality on students' entrepreneurial intention. Journal of Entrepreneurship in Emerging Economies, 8(2), 162-179.

Quan, X. (2012). Prior experience, social network, and levels of entrepreneurial intentions. Management Research Review, 35(10), 945-957.

Ridha, R. N., \& Wahyu, B. P. (2017). Entrepreneurship intention in agricultural sector of young generation in Indonesia. Asia pacific journal of innovation and entrepreneurship, 11(1), 76-89.

Singh Sandhu, M., Fahmi Sidique, S., \& Riaz, S. (2011). Entrepreneurship barriers and entrepreneurial inclination among Malaysian postgraduate students. International Journal of Entrepreneurial Behavior \& Research, 17(4), 428-449.

Segal, G., Borgia, D., \& Schoenfeld, J. (2005). The motivation to become an entrepreneur. International journal of Entrepreneurial Behavior \& research, 11(1), 42-57.

Tognazzo, A., Gianecchini, M., \& Gubitta, P. (2017). Educational Context and Entrepreneurial Intentions of University Students: An Italian Study. In Entrepreneurship Education: New Perspectives on Entrepreneurship Education (pp. 47-74). Emerald Publishing Limited.

Trivedi, R. (2016). Does university play significant role in shaping entrepreneurial intention? A cross-country comparative analysis. Journal of Small Business and Enterprise Development, 23(3), 790-811.

Turker, D., \& Sonmez Selçuk, S. (2009). Which factors affect entrepreneurial intention of university students?. Journal of European industrial training, 33(2), 142-159.

Yukongdi, V., \& Lopa, N. Z. (2017). Entrepreneurial intention: a study of individual, situational and gender differences. Journal of Small Business and Enterprise Development, 24(2), 333-352. 